\section{Rôle of government}

In "Nanoscience and the Environment" one of the "Science Notes" (undated) published by the UK Government's Department for Environment, Food and Rural Affairs (Defra), it is stated that "Government is currently reviewing the regulatory status of the products of nanotechnologies. It is likely that we will need to seek to modify European regulations in order to reflect future uses and risks." The impression made by the statement is one of a paternally concerned central administration wishing to ensure the best for its citizens. But what is "the best"? The minimalist response is based on individuals living in proximity pooling some of their individual freedom in order to be able to live more effectively. The condensed matter physicist will see an analogy in the formation of energy bands as atoms move together. This pooling may be as simple as coöperating with one's neighbours to build a stout enclosure around a group of individual dwellings in order to protect against fierce wild animals. Presumably, in all such cases, the loss of individual welfare (in this example, mainly through having to spend time coöperating with others in the building work) is less than the gain (not having to defend oneself and one's family individually, for example by setting a watch throughout the night). Much more sophisticated ways to quantitatively evaluate collective safety measures now exist [1]. ${ }^{1}$ Some such measures, such as agreeing on a "rule of the road" (keeping left or right when passing other vehicles) combine negligible cost with immense benefit in reducing accidents, hence calculations are hardly necessary.

"The best" could, therefore, encompass anything, provided there is a net benefit. An oppressive régime is one in which the collective burden exceeds benefits to the individual. Assuming that we are fundamentally free and independent beings, such oppression makes no sense and, when it occurs, the result is either emigration or revolution. It is really the responsibility of citizens to constantly assess the balance of collective and individual responsibilities; where there is imbalance, civic action (such as, in the UK, writing a letter to one's Member of Parliament) may suffice to effect a correction. In Britain and the British Commonwealth, maintaining the "Queen's peace" - an orderly environment for individual existenceis the primary requirement; many countries with more formalized written constitutions (such as the USA) specifically uphold certain "human rights" such as individual freedom.
In the course of time governments arose as quasiseparate entities, and as the scale of society increased they tended to become more and more separate, not least because of a disproportionate increase in their size. This increase-disproportionate with respect to their duties - may be traced back to the inevitable growth of any bureaucracy [2]. Despite a semblance of democratic control, in most so-called democracies these bureaucratic governments tended to become independent entities in their own right. ${ }^{2}$ From this arose the maximalist response to "what is the best?": to ensure the health and wealth of the population. Hence, we have national health services and programmes to "manage the economy", in which the aims are usually to generate economic growth, minimize inflation and maximize employment. Such programmes tend to lull individual citizens into thinking that they do not have to worry about very much any more - in effect they are reduced to clamouring for panem et circenses [3]. According to Yoshida [4], the third most important task of a man should be to learn the art of medicine, without which "a man cannot care for his own body, nor help others ...". It is curious that, despite exponentially increasing government expenditure on education, government expenditure on health also grows exponentially, suggesting that inadequate attention is given to the foundations of health education. As for wealth, the considered wisdom of the Bank for International Settlements [5] that "our understanding of economic processes may be even less today than it was in the past" makes attempts to manage the economy seem faintly absurd. Extensive empirical evidence amply demonstrates the dampening (or "crowding out") effect of government spending [6], and similarly inculcation of the expectation that "jobs will be provided" dampens individual entrepreneurialism. Yet, especially in matters concerning energy, correcting "market failures" appears to have become part of mainstream thinking [7].

An excellent testbed for evaluating possible rôles of government is the regulation of potentially harmful industries. The history of such regulation, at least in the USA, suggests an extremely confrontational and yet inextricably intertwined relationship between the three major parties involved: the manufacturers, the general public and the government [8]. The government depends on support from the general public, both at election time and, more importantly, through tax revenues; and these tax revenues are paid for out of income derived through

\footnotetext{
1 One advantage of the J-value formalism is that it is based not on economics alone but on quality of life.

2 The only exception is Switzerland, where laws and budgets are still voted on directly by all adult citizens. This in itself put a brake on the size of government, because bureaucracies, whose officials all have to be paid salaries, are expensive.
} 
employment by the manufacturers. The government also depends on corporation tax revenues, and the general public benefits from the products of the manufacturers (who would otherwise not exist). While government is sometimes seen as imposing regulation on hapless industrialists, in reality regulation, like standardization, is achieved through consensus-building [9].

Lead in petrol now largely belongs to the past; tobacco is still with us and the battles over pesticides (and, we might add, contaminated aircraft cabin air [10]) largely remain to be fought. In the past (i.e., in minimalist days) it would, at least in principle, have been possible to soberly assess the risks and benefits of any new technology; it was always a question of placing them in balance. But in a maximalist environment government is involved in so many ways it is itself riddled by internal conflict. Allowing a certain activity to take place may increase morbidity and, hence, place a burden on the state health service; intensifying the activity may increase mortality, which would lead to significant economies in the social security (state pension) budget. Are policies of regulation to be decided on the basis of which government department has the strongest influence with the state treasury? If that were so, societally destructive conflicts could be avoided by the judicious grouping of different departments into common entities so as to eliminate the possibilities of creating internal financial advantage through interdepartmental competition.

The difficulties are compounded by the fact that some of the relevant diseases, especially cancers, have extremely long incubation times. If morbidity or mortality occurs during the interval of taxable revenue-generating activity of the citizen, it will result in a loss of government income. ${ }^{3}$

An additional difficulty associated with some of the most egregious examples of chemical pollution is that, either directly or indirectly (e.g., through sequestering trace elements essential for infant development) the general level of intelligence of the population might be adversely affected. This is somewhat analogous to concerns about the medical benefits of radiographic screening being offset by the same radiation causing deleterious genetic mutations. Happily, in that case the former seems to overwhelmingly preponderate over the latter but in the case of the trace element deficiencies our knowledge is still woefully inadequate and it is not yet possible to make calculations in sufficient detail to be useful as a guide to policy.

\section{J.J. RAMSDEN}

\section{References}

1. Thomas, P.J., Stupples, D.W. and Alghaffar, M.A. The extent of regulatory consensus on health and safety expenditure. Part 1. Development of the J-value technique and evaluation of the regulators' recommendations. Trans. IChemE, Part B (Process Safety and Environmental Protection) 84 (2006) 329-336.

2. Parkinson, C. N. Parkinson's Law. Harmondsworth: Penguin (1965).

3. Juvenal, D.J. Satires (Satura X). Rome ( ca 100).

4. Yoshida, K. Tsuredzure-gusa. Jyo-Gyo (?) (ca 1330?).

5. 77th Annual Report, p. 139. Basel: Bank for International Settlements (2007).

6. Kealey, T. Sex, Science \& Profits. London: Vintage Books (2009).

7. E.g. Bjornstad, D.J. and Brown, M.A. A Market Failures Framework for Defining the Government's Role in Energy Efficiency. Knoxville, Tennessee: Joint Institute for Energy and Environment (2004).

8. Michaels, D. Doubt Is Their Product. Oxford: University Press (2008).

9. Reed, P. Robert Angus Smith and the Alkali Inspectorate. In: The Chemical Industry in Europe, 1850-1914 (eds E. Homburg, A.S. Travis and H.G. Schröter), ch. 8 (pp. 149-163). Springer (1998).

10. J. Biol. Phys. Chem. 11 (December 2011).

\footnotetext{
3 A further difficulty is imposed by the frenetic pace of parliamentary, presidential etc. elections, which is widely considered to be a hallmark of a "good" democracy. The thinking is - presumably - that a politician can be held accountable by voting him or her out of office at the next election. Looking at the currently chaotic state of most national affairs, one concludes that this system is not very effective-four years (which seems to be the most popular interval) is probably far too short in most cases to properly evaluate outcomes (besides, its brevity encourages short-termism from the outset). The desire to limit the possibilities for corruption associated with long terms of office evidently predominates over a willingness to recognize that the office holder may be motivated by personal integrity and full acceptance of the responsibilities of office, and if he is incompetent why was he voted in in the first place? France reduced the mandate of her president from 7 to 5 years in 2000, and in 2008 limited the number of consecutive terms of office to two; possibly as a result of following this trend towards short-termism, it is scarcely possible to discern any coherence in French state policies today.
} 